\title{
Prevalence of Sickle Cell Disease and Other Haemoglobin Variants in Calabar, Cross River State, Nigeria
}

\author{
Akaba Kingsley ${ }^{1 *}$, Ofem Enang ${ }^{2}$, Ofonime Essien ${ }^{1}$, Annette Legogie $^{3}$, \\ Omini Cletus ${ }^{1}$ and Olukayode Oshatuyi ${ }^{4}$ \\ ${ }^{1}$ Department of Haematology and Blood Transfusion, University of Calabar Teaching Hospital, \\ Calabar, Nigeria. \\ ${ }^{2}$ Department of Internal Medicine, University of Calabar Teaching Hospital, Calabar, Nigeria. \\ ${ }^{3}$ Department of Family Medicine, University of Calabar Teaching Hospital, Calabar, Nigeria. \\ ${ }^{4}$ Department of Biochemistry, Ebonyi State University, Abakaliki, Nigeria.
}

\begin{abstract}
Authors' contributions
This work was carried out in collaboration among all authors. Authors AK and O. Enang designed the study, performed the statistical analysis, wrote the protocol and wrote the first draft of the manuscript.

Authors $O$. Essien and OC managed the analyses of the study. Author OO managed the literature searches. All authors read and approved the final manuscript.

Article Information

DOI: $10.9734 / A R R B / 2019 /$ v33i530132 Editor(s):

(1) Dr. Bechan Sharma, Department of Biochemistry, University of Allahabad, India.

Reviewers:

(1) Nwogoh Benedict, University of Benin, Nigeria.

(2) Karen Cordovil, Oswaldo Cruz Foundation, Brazil.

(3) Nirmal Kr. Pradhan, University of Burdwan, India.

(4) Edhyana Sahiratmadja, Universitas Padjadjaran, Indonesia.

Complete Peer review History: https://sdiarticle4.com/review-history/52584
\end{abstract}

Original Research Article

Received 02 September 2019

Accepted 06 November 2019

Published 13 November 2019

\section{ABSTRACT}

Background: Sickle cell disease (SCD) is the commonest genetic disorder worldwide with a global prevalence of 20-25 million. About 12-15 million affected persons are in Sub-Sahara Africa with Nigeria bearing the highest burden of people living with sickle cell disease. SCD is a disease characterized as an autosomal, recessive, heterogeneous, and a monogenetic disorder caused by an A-to-T point mutation in the $\beta$-globin gene responsible for the production of abnormal hemoglobin $\mathrm{S}(\mathrm{HbS})$, which polymerizes in the deoxygenated state and results in the sickling of erythrocytes. Haemoglobin variants are mutant forms of haemoglobin in a population usually occurring as a result 
of genetic changes in specific genes, or globins that causes change on alterations in the amino acid. They could affect the structure, behavior, the production rate and the stability of the specific gene. Well-known haemoglobin variants such as sick-cell anaemia are responsible for diseases and are considered haemoglobinopathies. Other variants cause no detectable pathology and are thus considered as non-pathological variants.

Aim: The study is aimed at evaluating the burden of sickle cell disease and other haemoglobin variants in Calabar, South-South Nigeria.

Methods: This is a retrospective study done at the haematology laboratory of University of Calabar Teaching Hospital, Calabar. Cellulose acetate electrophoresis at alkaline $\mathrm{pH}$ was used for the evaluation of haemoglobinopathies. The data were entered into Microsoft Excel 2016 spreadsheet and analysed with the IBM SPSS Version 22. Data were summarized into percentage of different phenotypes.

Results: Results of the total 3648 haemoglobin electrophoresis recorded, $1368(37.50 \%)$ were male while the remaining $2280(62.5 \%)$ females given a male to female ratio of $1: 1.7$. Five haemoglobin phenotypes were identified as $\mathrm{HbAA}, \mathrm{HbAS}, \mathrm{HbAC}, \mathrm{HbSC}$ and $\mathrm{HbSS}$. The overall average values of their prevalence were $\mathrm{HbAA} 64.78 \%$, HbAS $32.62 \%$, HbSS $2.14 \%$, HbAC $0.33 \%$, HbSC $0.14 \%$. Thus, the prevalence of SCD (Prevalence of $\mathrm{HbSS}+\mathrm{HbSC}$ ) was $2.28 \%$. The highest proportion of SCD was observed in 2011 with least in 2016 and 2017 respectively.

Conclusion: The prevalence of SCD and other haemoglobin variants in Calabar is similar to that of the national prevalence rate. There is need for continuous enlightenment and premarital counselling on the pattern of inheritance of SCD most especially with the increased burden of sickle traits in the environment has reported in this study.

Keywords: Haemoglobin; phenotype; sickle cell disease; Calabar.

\section{INTRODUCTION}

Haemoglobin $(\mathrm{Hb})$ is a Greek word that is derived from two words: Haem and Globin which means blood and protein respectively. The globin comprises of a set of closely related protein formed by the symmetric pairing of dimer of polypeptide chains of $\alpha$ and $\beta$ globin into a tetramer with structural and functional unit in the red blood cell [1].

Haemoglobin is responsible for the transport of oxygen from the lung to the tissue and carry $\mathrm{CO}_{2}$ from the tissue to the lung for gaseous exchange. Also, haemoglobin serves as a buffer to maintain the $\mathrm{pH}$ of the physiology milieu of the body [2].

There are different types of $\mathrm{Hb}$ and their globin chain composition varies at different stages of life. During fetal life, Gower I, Portland, Gower II, and fetal $\mathrm{Hb}$ predominate in uterine life [2] there is a transition to adult $\mathrm{Hb}$ within 3-6 month of life [3].

Various genetic mutations affect the $\mathrm{Hb}$. They could be quantitative or qualitative leading to various forms of haemoglobinopathies such as thalassaemias and $\mathrm{HbS}, \mathrm{HbC}, \mathrm{HbE}$, and $\mathrm{HbD}$ among others [2]. These haemoglobinopathies arise from either homozygous, heterozygous or compound heterozygous genetic mutations resulting in various clinical presentations. The inheritance of an $S$ gene is termed sickle cell disorder. The $\mathrm{HbS}$ gene is due to point mutation at position 6 of the $\beta$ globin chain with substitution of valine for glutamic acid while the $C$ gene is due to substitution of lysine for glutamate at position 6 of the $\beta$ chain [3].

Sickle Cell Disease (SCD) is a disease characterized as an autosomal, recessive, heterogeneous, and monogenetic disorder. The disease is caused by the inheritance of the sickle cell gene either the homozygous or heterozygous with another interacting gene [4]. The homozygous state is referred to as sickle cell anaemia and may be characterized by increased red cell destruction (haemolysis) amongst other clinical features. There is inconsistency and geographical variation in the available data on the $\mathrm{Hb}$ variants in our environment with paucity of study in our environment. The aim of this study is to evaluate the major $\mathrm{Hb}$ variants and the burden of sickle cell disease in Calabar.

\section{MATERIALS AND METHODS}

This is a retrospective study. Results of haemoglobin electrophoresis of patients done at the haematology laboratory of the University of Calabar Teaching Hospital (UCTH) Calabar from 
Jan 2008 to September 2019 were analyzed. Cellulose acetate electrophoresis at alkaline $\mathrm{pH}$ was used for the evaluation of haemoglobinopathies. Various forms of haemoglobin phenotypes documented was used for the analysis. A total of three thousand six hundred and forty-eight haemoglobin phenotypes results were documented during the study period.

The data were computed into Microsoft Excel 2016 spreadsheet and analysed with the IBM SPSS Version 22. Data were summarized as percentage of different phenotypes including, normal $\mathrm{HbAA}$ and mutant allele(s) in the genotype; HbAS, HbAC, HbSS, and HbSC.

\section{RESULTS}

The eleven-year records of 3648 haemoglobin electrophoresis of patients showed that 1368 $(37.50 \%)$ were male while the remaining 2280 $(62.5 \%)$ females given a male to female ratio of 1:1.7 (Table 1). Five haemoglobin phenotypes were identified namely $\mathrm{HbAA}, \mathrm{HbAS}, \mathrm{HbAC}$, $\mathrm{HbAS}$, and $\mathrm{HbSS}$. The overall prevalence was $\mathrm{HbAA} 64.78 \%$, HbAS 32.62\%, HbSS 2.14, HbAC $0.33 \%$, HbSC $0.14 \%$. Thus, the prevalence of SCD (Prevalence of $\mathrm{HbSS}+\mathrm{HbSC}$ ) was $2.28 \%$ (Table 2). The highest proportion of SCD was documented in 2011 and least seen in 2017 (Fig. 1). The mean age documented was $22.98 \pm 2.84$ (SD) years (Fig. 2).

\section{DISCUSSION}

SCD is the commonest genetic disorder worldwide with a global prevalence of 20-25 million. About 12-15 million affected persons are in Sub-Sahara Africa with Nigeria having the highest burden of people living with sickle cell disease [5]. SCD affects about 2-3\% of the Nigerian population [6], in our study, a prevalence of $2.28 \%$ was reported.

This study found the prevalence of $64.78 \%$ for $\mathrm{HbAA}, 32.62 \%$ for AS, $2.14 \%$ for SS, $0.33 \%$ for $A C$, and $0.14 \%$ for SC with female preponderance. This is similar to the finding which showed $\mathrm{HbAA}$ at $55-75 \%$, AS $20-30 \%$, SS $1-3 \%$ [7] and a study by Olagunju et al. [8]. Nwogoh et al also reported similar findings [9], another study by Adu et al also reported similar findings in terms of SC and SS respectively [10]. Furthermore, a previous study conducted by Udomah et al. [11] on haemoglobin electrophoretic patterns, $A B O$ and Rhesus $D$ blood groups distribution among antenatal women in Sokoto, Nigeria reported a similar prevalence of SC (0.3\%), AC $3.7 \%$, AS $22.3 \%$ and AA $73.3 \%$. Although, the findings are at variance with a similar study by Odunvbum et al which reported a higher prevalence of $75.3 \%$ for AA, $20.6 \%$ for AS, $1.1 \%$ for AC, $2.8 \%$ for SS and $0.2 \%$ for SC [12]. This difference can be attributed to the difference in study design and increase infant and under-five mortality.

More so, a study conducted in Northern Nigeria by Baba Inusa et al. reported a higher prevalence of SCD when compared with our study. They reported a prevalence of $2.69 \%$ [13]. This also can be attributed to the difference in study design and consanguineous marriage encouraged by Islamic practice which may contribute to the high prevalence of $\mathrm{HbSS}$ in Northern Nigeria. Another study conducted

Table 1. Gender distribution of haemoglobin variants

\begin{tabular}{lllllll}
\hline Gender & \multicolumn{5}{c}{ Haemoglobin typing } & Total \\
\cline { 2 - 6 } & AA & AS & SS & SC & AC & \\
\hline Male & 898 & 433 & 30 & 3 & 4 & 1368 \\
Female & 1464 & 758 & 48 & 2 & 8 & 2280 \\
\hline Total & 2362 & 1191 & 78 & 5 & 12 & 3648 \\
\hline
\end{tabular}

Table 2. Prevalence of haemoglobin phenotype variants in Calabar

\begin{tabular}{lll}
\hline HB phenotypes & Frequency & Percentage \\
\hline AA & 2363 & 64.78 \\
AS & 1190 & 32.62 \\
SS & 78 & 2.14 \\
AC & 12 & 0.33 \\
SC & 5 & 0.14 \\
SCD (SS+SC) & 83 & 2.28 \\
\hline
\end{tabular}




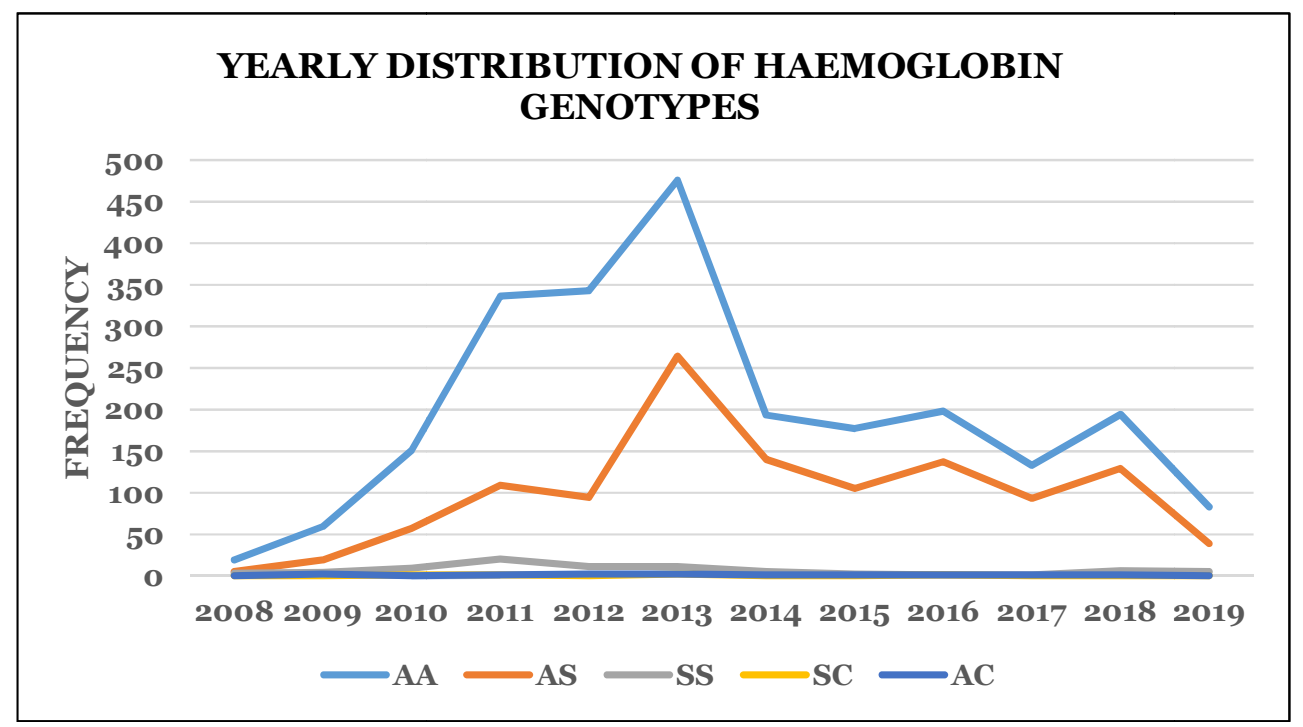

Fig. 1. Yearly distribution of haemoglobin phenotype variants

in Southwest Nigeria by Akhigbe et al. [14] reported a lower prevalence of AS (22.19\%) and SS (0.56\%). Similarly, Akinboro et al also reported a low prevalence of $10.23 \%$ for AS in a study conducted in Akure [15]. However, another study conducted by Bakare et al. [16] in Ogbomoso, south-west Nigeria, a higher prevalence of SS (3\%) and SC (2\%) was reported. The variation here could be attributed to the difference in literacy rate and increase in the number of specialist for easy detectability of the disease condition, and the high incidence of
$\mathrm{HbC}$ trait that is largely confined to the Yoruba people of southwestern Nigeria [17]. A similar study conducted by Nnaji in Southeast Nigeria [18] also reported a lower value for AS (26.4\%) and SS (0.94\%). Also, David Agatha Nikruka reported a lower prevalence of AS (18.8\%) in the same region [19]. The difference observed in the Southeast region could be attributed to the increase in the availability of Specialists and even distribution of tertiary health facilities. These allows for early diagnosis and prevention of the disease condition.

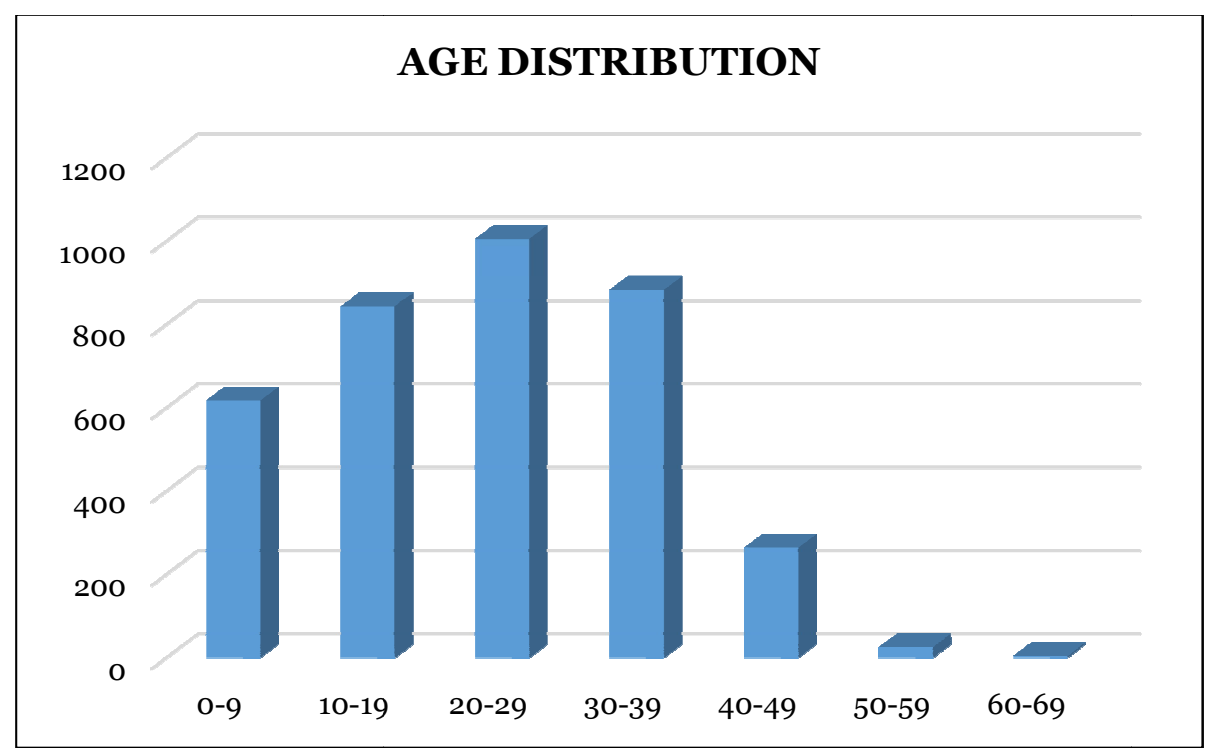

Fig. 2. Showing the age distributions 
In the index study, the peak incidence of SCD was in 2011 with least incidence in 2017. The high incidence could be attributed to high level of illiteracy, Spiritism, inadequate specialist (manpower), lack of infrastructure and difficulty in accessing health facility, inadequate enlightenment while the decline could be attributed to increasing manpower, education and establishment of advocacy groups.

\section{CONCLUSION}

The percentage of $\mathrm{HbAA}$ is maintained and the prevalence of haemoglobinopathies in the studied group is within the national prevalence. The study showed that the disease condition is not in the Hardy-Weinberg equilibrium (HardyWeinberg equilibrium is a principle stating that the genetic variation in a population will remain constant from one generation to the next in the absence of disturbing factors), indicating that with continuous enlightenment, pre-marital, genetic counselling and adequate political will, the disease can be curbed or ultimately eradicated.

\section{LIMITATION OF THE STUDY}

This study has some limitation, one of which is the bias for the methodology because some abnormal haemoglobin with similar electrophoretic mobilities must be detected using other techniques.

\section{IMPLICATION OF THE STUDY}

The implication of our finding is that the reducing trend of SCD in our environment is still characterized with the challenge of increased burden of sickle cell trait (AS) which allude to an upsurge of this disease condition if adequate enlightenment, premarital counselling and education on the pattern of inheritance of this disease condition is not done to mitigate this menace by all stakeholders involved in the management of sickle cell disease. Therefore, it is pertinent that a pre-marital counselling clinic should be established and strong legislation should be enacted to encourage genetic counselling and testing before marriage.

\section{COMPETING INTERESTS}

Authors have declared that no competing interests exist.

\section{REFERENCES}

1. Perutz MF. Regulation of oxygen affinity of haemoglobin: Influence of structure of the globin on the heme iron. Ann. Rev. Biochem. 1979;48:327-86.

2. Lichtman MA, Kipps TJ, Seligsohn U, Kaushansky K, Paschal TJ. Disorders of haemoglobin structure: Sickle cell anaemia \& related abnormalities' in Williams Haematology, $8^{\text {th }}$ edition. Landsteiner publications Chapter. 2010;48:871-914.

3. Hoffbrand AV, Moss PAH, Moss Petit JE. Genetic disorders of haemoglobin: In Essential Haematology, $5^{\text {th }}$ edition, UK, Blackwell Publishing Ltd. 2006;6:7293.

4. Akaba K, Ofem E, Bassey OB, Oluwakorede B, Riman O. Biochemical assessment of the liver in SCD in a tertiary hospital in South-South, Nigeria. Journal of Advances in Medicine and Medical Research. 2019;29(7):1-6.

5. Babadoko AA, Ibinaye PO, Hassan A. Autosplenectomy of sickle cell disease in Zaria, Nigeria. Oman Med. J. 2012;27(2): 121-123.

6. Akaba K, Inyama M, Ekwere T, Iheanacho O, Bassey E, Ushie G, Archibong H, Efiok E. Haemostatic disorders in sickle cell disease subjects in Nigeria: A review of literature. International Blood Research \& Reviews. 2018;8(4):1-7.

7. Nwafor A, Banigo BM. A comparison of measured and predicted state. Nig. J. Appl. Sci. Environ Mangt. 2001;5(1):79-81.

8. Olagunju OE, Faremi FA, Olaifa O. Prevalence and burden of sickle cell disease among undergraduates of Obafemi Awolowo University, Ile-Ife. Journal of Community Medicine and Primary Health Care. 2017;29(1):74-80.

9. Nwogoh B, Adewoyin A, Iheanacho OE, Bazuaye GN. Prevalence of haemoglobin variants in Benin City, Nigeria. Ann Biomed Sci. 2012;11(2):61-64.

10. Adu EM, Isibor CN, Ezie E. Prevalence of haemoglobin variants among the lka ethnic nationality of Delta state. Int J Med Biomed Res. 2014;3(2):63-67.

11. Udomah FP, Isaac IZ, Aliyu N, Erhabor O, Ahmed $\mathrm{MH}$, et al. Haemoglobin electrophoretic patterns, $\mathrm{ABO}$ and Rhesus $D$ blood groups distribution among antenatal women in Sokoto, Nigeria. 
Obstet Gynecol Cases Rev. 2015;2:3438.

12. Odunvbun ME, Okolo AA, Rehimy CM. Newborn screening for sickle disease in a Nigerian hospital. Public Health. 2008; 122:1111-1116.

13. Baba PI, Daniel Y, Lawson JO, Dada J, Matthews CE, Sukhleen M, Obaro SK. Sickle cell disease screening in Northern Nigeria: The co-existence of B-thalassemia inheritance. Paediatrics \& Therapeutics. 2015;5(3):1-4.

14. Akhigbe RE, Ige SF, Afolabi AO, Azeez OM, Adegunlola GJ, Bamidele JO. Prevalence of haemoglobin variants, $A B O$ and Rhesus Blood Groups in Ladoke Akintola University of Technology, Ogbomoso, Nigeria. Trends Med. Res. 2009;4:24-29.

15. Akinboro A, Komolafe EK, Musibau AAA retrospective study on fourteen-year haemoglobin genotype variants recorded at five government hospitals in Akure, Ondo State, Southwestern Nigeria. The
Egyptian Journal of Medical Human Genetics. 2016;17:377-381.

16. Bakare AA, Azeez MA, Agbolade JO, Gene frequencies of $A B O$ and rhesus blood groups and haemoglobin variants in Ogbomoso, South-West, Nigeria. Global J. Med. Sci. 2004;3:17-22.

17. Akinyanju OO. A profile of sickle cell disease in Nigeria. Annals of the New York Academy of Sciences. 1989;565(1 sickle cell D):126-136.

18. Nnaji GA, Ezeagwuna DA, Nnaji IJF, Osakwe JO, Nwigwe AC, Onwurah OW. Prevalence and pattern of sickle cell disease in premarital couples in Southeastern Nigeria. Nig. J. Clin Prac. 2013;16(3):1-6.

19. David AN, Jinadu MY, Wapmuk AE, Gbajabiamila TA, Okwuzu O, Herbertson EC, Ezechi OC. Prevalence and impact of sickle cell trait on the clinical and laboratory parameter of HIV infected children in Lagos, Nigeria. 2018;31:113120.

(c) 2019 Kingsley et al.; This is an Open Access article distributed under the terms of the Creative Commons Attribution License (http://creativecommons.org/licenses/by/4.0), which permits unrestricted use, distribution, and reproduction in any medium, provided the original work is properly cited.

Peer-review history:

The peer review history for this paper can be accessed here: https://sdiarticle4.com/review-history/52584 